\title{
Pemutihan kembali gigi yang berubah warna pada anak Dental bleaching on children with discolored teeth
}

\author{
Roedy Budirahardjo \\ Bagian Pedodonsia \\ Fakultas kedokteran Gigi Universitas Jember \\ Jember, Indonesia
}

\begin{abstract}
Dental bleaching is a process making teeth look whiter. Bleaching may be performed in two methods; by using bleaching products or non-bleaching products. Bleaching products contain peroxide assisting to remove intrinsic and extrinsic stain, resulting in the changing of original color of teeth. Non-bleaching products contain materials that may work to remove extrinsic stain only, through both physical and chemical actions. The use of bleaching products is not always safe, therefore, they should be assumed that their benefits are over their recognized biological risk. The choice of bleaching method for children depends on type and depth of the stain, and discoloring. Stain on the enamel surface can be removed by microabration, deeper stain is removed by bleaching. Besides using approved by ADA/ISO, a dental practitioner should have knowledge about dental bleaching and its use at clinic and at home, including its contraindication as well as side effect in order to provide an effective and satisfying dental bleaching care.
\end{abstract}

Key words: dental bleaching, intrinsic stain, extrinsic stain

\begin{abstract}
ABSTRAK
Pemutihan gigi adalah suatu proses untuk membuat gigi tampak lebih putih. Memutihkan gigi bisa dicapai dengan dua cara, yaitu menggunakan produk bleaching atau non-bleaching. Produk bleaching mengandung peroksida yang membantu menghilangkan stain instrinsik dan ekstrinsik, hasilnya dapat mengubah warna alami gigi. Produk nonbleaching mengandung bahan yang bekerja menghilangkan stain dengan aksi fisik dan kimia, hanya untuk stain ekstrinsik. Pemakaian bahan pemutih gigi tidak selalu aman, oleh karena itu untuk penggunaannya harus diasumsikan bahwa keuntungannya jauh melebihi risiko biologis yang diketahui. Pemilihan cara bleaching pada anak tergantung pada jenis stain, perubahan warna dan dalamnya stain. Stain pada permukaan email dapat dihilangkan dengan cara mikrobrasi dan bila lebih dalam harus dengan cara bleaching. Selain menggunakan bahan pemutih yang telah disetujui ADA/ISO, dokter gigi harus memiliki pengetahuan mengenai pemutihan gigi di klinik, penggunaan pemutih gigi di rumah, dan juga kontraindikasi serta efek samping agar dapat memberikan pelayanan pemutihan gigi yang efektif dan memuaskan.
\end{abstract}

Kata Kunci: pemutihan gigi, stain ekstrinsik, stain intrinsik

Koresponden: Roedy Budirahardjo. Bagian Pedodonsia Fakultas Kedokteran Gigi Universitas Jember, J1 Kalimantan 37 Jember 68121, Indonesia. E-mail:

\section{PENDAHULUAN}

Keinginan masyarakat masa kini terhadap kualitas tampilan gigi mereka semakin meningkat. Gigi tidak cukup terlihat rapi tetapi juga harus putih. Pada saat ini pemutihan gigi dalam kedokteran gigi estetik sangat cepat berkembang. Masyarakat kini sudah lebih mengenal kedokteran gigi estetik melalui berbagai media dan iklan. Dengan demikian, banyak orang tua yang berminat akan pemutihan gigi anak mereka. ${ }^{1}$

Pemutihan gigi adalah suatu proses yang akan membuat gigi tampak lebih putih. Memutihkan gigi bisa dicapai dengan dua cara, yaitu menggunakan produk bleaching atau nonbleaching. Produk bleaching mengandung peroksida yang membantu menghilangkan stain dalam gigi (instrinsik) dan permukaan gigi (ekstrinsik), hasilnya dapat mengubah warna asli gigi. Produk pemutih non-bleaching, mengandung bahan yang bekerja menghilangkan stain dengan aksi fisik dan kimia, hanya untuk stain di permukaan gigi. ${ }^{2}$ Pemakaian bahan pemutih gigi tidak selalu aman, oleh karena itu bahan pemutih gigi harus diasumsikan bahwa keuntungan penggunaannya jauh melebihi risiko biologis yang diketahui. Mutu dan sifat bahan pemutih gigi harus mempunyai standar spesifikasi yang dapat diukur, perlu diidentifikasi persyaratan sifat fisik dan kimia, sehingga didapatkan hasil yang memuaskan dan tepat guna. ${ }^{3}$

Indikasi klinik untuk memutihkan gigi anak adalah pada kasus perubahan warna gigi karena traumatic injury, warna email gigi permanen anak yang tidak merata karena trauma, atau infeksi yang berhubungan dengan gigi sulung. Selain itu oleh karena adanya perubahan warna intrinsik, 
antara lain oleh karena fluorosis dan tetrasiklin. Umumnya penggunaan pemutih gigi dilakukan pada orang dewasa, meskipun penelitian yang membahas pemutihan gigi pada anak masih sedikit, tetapi kepustakaan mengindikasikan pemutihan gigi pada anak sangat berguna. ${ }^{2}$

Warna normal gigi sulung adalah putih kebiru-biruan atau putih susu. Warna normal gigi permanen adalah kuning keabu-abuan. Perubahan warna dapat berlangsung secara fisiologi maupun patologi. Perubahan warna fisiologi terjadi seiring dengan bertambahnya usia, karena dentin lebih tebal, akibat pembentukan dentin sekunder dan dentin reparatif. Perubahan warna secara patologis dapat secara ekstrinsik dan intrinsik. Perubahan warna secara ektrinsik dapat disebabkan oleh deposit yang terjadi pada permukaan gigi. Sementara perubahan warna gigi secara intrinsik disebabkan oleh faktor dari dalam jaringan pulpa. ${ }^{4}$

Pada makalah kajian pustaka ini akan dibahas mengenai cara dan bahan pemutih gigi yang tepat guna dan aman bagi anak.

\section{TINJAUAN PUSTAKA}

Kandungan utama bahan pemutih gigi tergantung dari produsen pembuatnya, diantaranya hidrogen peroksida,karbamid peroksida atau urea peroksida atau sistem non-hidrogen peroksida yang mengandung sodium klorida, oksigen dan natrium fluorida. Beberapa produk mengandung bahan tambahan potasium nitrat dan fluoride untuk membantu mengurangi sensitivitas gigi.

Menurut Grossman ${ }^{4}$ perubahan warna gigi dapat diklasifikasikan atas perubahan warna gigi ekstrinsik dan intrinsik. Perubahan warna ekstrinsik ditemukan pada permukaan luar gigi dan biasanya bersifat lokal, seperti misalnya stain pada tembakau dan teh. Beberapa perubahan warna gigi ekstrinsik, misalnya diskolorisasi hijau yang dihubungkan dengan membran Nasmyth pada anak-anak, dan noda teh serta tembakau, dapat dihilangkan dengan skaling dan pemolesan pada waktu profilaksis gigi. Jenis lain diskolorisasi ekstrinsik, seperti noda nitrat perak, hampir tidak dapat dihilangkan tanpa diasah karena stain memasuki permukaan mahkota dan sukar dihilangkan hanya dengan bahan-bahan kimiawi saja.

Perubahan warna intrinsik adalah noda yang terdapat dalam email dan dentin yang disebabkan oleh penumpukan atau penggabungan bahan seperti stain tetracycline. Bila masuk ke dalam dentin menjadi kelihatan karena translusensi email. Dapat dihubungkan dengan periode perkembangan gigi, seperti pada dentinogenesis imperfekta, atau dapat terjadi setelah selesainya perkembangan gigi, seperti pada nekrosis pulpa. Diskolorisasi intrinsik seperti yang terjadi pada amelogenesis imperfekta tidak mungkin dihilangkan karena berasal dari kerusakan perkembangan email dan dentin. Akan tetapi stain yang disebabkan karena nekrosis, dapat dihilangkan dengan prosedur pemutihan.

Menurut Walton, ${ }^{5}$ perubahan warna dapat terjadi pada saat atau setelah terbentuknya email dan dentin. Penyebab perubahan warna gigi dapat dibagi menjadi dua kelompok, yaitu karena noda alami dan pewarnaan iatrogenic (tabel 1).

Perubahan warna gigi akibat noda alami disebabkan oleh sejumlah noda pada permukaan gigi setelah gigi erupsi. Noda alami mungkin berada pada permukaan atau berikatan di dalam struktur gigi, kadang-kadang diakibatkan defek email atau karena trauma. Contoh penyebab noda alami adalah pulpa nekrosis, obat-obatan sistemik dan defek saat pembentukan gigi.

Produk kerusakan jaringan yang dilepaskan masuk ke dalam tubulus dentin akan mewarnai dentin di sekitarnya. Kerusakan jaringan antara lain perdarahan intrapulpa, metamorfosis kalsium, dan defek perkembangan.

Perdarahan intrapulpa disebabkan oleh trauma pada gigi dan akan menyebabkan perdarahan dan lisis eritrosit. Produk disintegrasi darah diduga sebagai ion sulfida, masuk ke dalam tubulus dentin sehingga menyebabkan perubahan warna gigi.

Metamorfosis kalsium, pembentukan dentin sekunder ireguler secara ekstensif di dalam kamar pulpa atau pada dinding saluran akar menyebabkan translusensi mahkota gigi berkurang atau warna gigi berubah menjadi kekuningan atau kuning kecoklatan. Pada pasien yang sudah tua, perubahan warna gigi terjadi secara fisiologi sebagai akibat aposisi dentin secara berlebihan disamping karena penipisan dan perubahan optik dalam email.

Perubahan warna dapat terjadi karena defek pada saat perkembangan gigi antara lain fluorosis endemik,yaitu masuknya sejumlah flour saat pembentukan gigi menyebabkan kerusakan struktur yang mengalami mineralisasi dan mengakibatkan terjadinya hipoplasia sehingga permukaan gigi menjadi porus dan akan menyerap warna di dalam rongga mulut. Selain itu, masuknya obat-obatan atau bahan kimia secara sistemik pada saat pembentukan gigi dapat perubahan warna gigi. Yang paling berat adalah 
tetrasiklin, menyebabkan gigi berwarna kuning kecoklatan sampai abu-abu tua, tergantung jumlah, frekuensi, jenis tetrasiklin dan umur pasien saat meminum obat. Sementara defek dalam pembentukan gigi_terjadi sebatas email berupa hipoplasia atau hipokalsifikasi,terlihat warna gigi kecoklatan. Adanya kelainan darah dan faktor-faktor lain mengakibatkan lisis eritrosit secara luas. Produk kerusakan darah dapat bergabung ke dalam dentin dan mewarnai gigi. Suhu tubuh yang tinggi saat pembentukan gigi juga menyebabkan perubahan warna berbentuk pita pada email._Porfiria penyakit metabolisme menyebabkan gigi susu atau gigi permanen berubah warna menjadi kemerahan atau kecoklatan. Penyakit sistemik dan masuknya bahan obat-obatan, merupakan kejadian yang jarang dan tidak dapat diidentifikasi.

Perubahan warna iatrogenik sebagai akibat prosedur perawatan gigi atau dapat disebabkan oleh berbagai bahan kimia dan bahan yang dipakai di bidang kedokteran gigi. Perubahan warna gigi akibat perawatan endodontik dapat disebabkan oleh bahan obturasi, misalnya semen saluran akar dari jenis seng oksida eugenol atau semen saluran akar dengan komponen logam. Sisa-sisa jaringan pulpa yang tertinggal di dalam mahkota, biasanya dalam tanduk pulpa, dapat mengakibatkan perubahan warna secara perlahan. Kebanyakan obat-obatan dapat menyebabkan perubahan warna gigi, misalnya obat intrakanal golongan fenol berkontak langsung dengan dentin, dalam waktu yang lama memungkinkan obat berpenetrasi ke dalam dentin sehingga akan menyebabkan perubahan warna gigi.

Perubahan warna gigi karena restorasi dapat disebabkan karena logam amalgam dan komposit. Amalgam merupakan penyebab paling hebat karena elemen warna gelap dapat mengubah warna dentin menjadi abu-abu gelap. ${ }^{5}$ Sedangkan pada restorasi komposit, kebocoran mikro tumpatan dapat menyebabkan perubahan warna gigi. Tepi tumpatan yang terbuka merupakan tempat masuknya bahan kimia yang mewarnai dentin. $^{6}$

\section{Batas usia memulai pemutihan gigi}

Tidak ada batas usia yang jelas untuk memulai perawatan pemutihan gigi. Ada yang menyatakan pemutihan gigi dengan bleaching atau microabration boleh dilakukan pada anak berusia enam atau tujuh tahun. Bussadori et al melaporkan kasus pemutihan gigi 11 dan 21 karena adanya noda putih fluorosis menggunakan hidrogen peroksida $35 \%$ dengan aktivasi sinar pada pasien usia 8 tahun. Akan tetapi, ada juga yang tidak

Tabel 1. Penyebab perubahan warna gigi dari faktor ekstrinsik maupun faktor instrinsik (Sumber: Meizarini A, Riani D. Bahan pemutih gigi dengan sertifikat ADA/ISO. Majalah kedokteran Gigi 2005; 38(2): 25). ${ }^{3}$

\begin{tabular}{|c|c|c|c|}
\hline & Penyebab perubahan warna gigi & & Warna gigi \\
\hline $\begin{array}{l}\text { Faktor dari luar } \\
\text { gigi }\end{array}$ & $\begin{array}{l}\text { Kesehatan mulut jelek, kopi, teh, } \\
\text { makanan produk tembakau }\end{array}$ & & $\begin{array}{l}\text { Kuning, coklat, hijau,hitam, } \\
\text { coklat sampai hitam,kuning } \\
\text { kecoklatan sampai hitam }\end{array}$ \\
\hline \multirow[t]{4}{*}{$\begin{array}{l}\text { Faktor dari dalam } \\
\text { gigi }\end{array}$} & $\begin{array}{l}\text { Obat-obatan selama pertumbuhan } \\
\text { gigi }\end{array}$ & $\begin{array}{l}\text { tetrasiklin } \\
\text { fluoride }\end{array}$ & $\begin{array}{l}\text { garis coklat, abu-abu,hitam } \\
\text { bercak atau garis coklat, } \\
\text { putih }\end{array}$ \\
\hline & $\begin{array}{l}\text { Obat-obatan setelah pertumbuhan } \\
\text { gigi Penyakit/kondisi selama } \\
\text { pertumbuhan gigi }\end{array}$ & $\begin{array}{l}\text { minocycline } \\
\text { kondisi kelainan darah } \\
\text { trauma }\end{array}$ & $\begin{array}{l}\text { coklat, abu-abu merah } \\
\text { coklat, ungu biru, hitam } \\
\text { coklat }\end{array}$ \\
\hline & Perubahan pada pulpa & $\begin{array}{l}\text { obliterasi saluran akar } \\
\text { nekrosis pulpa dengan } \\
\text { perdarahan } \\
\text { nekrosis pulpa tanpa } \\
\text { perdarahan }\end{array}$ & $\begin{array}{l}\text { kuning } \\
\text { abu-abu, hitam } \\
\text { kuning, abu-abu kecoklatan }\end{array}$ \\
\hline & Penyebab lain pada gigi nonvital & $\begin{array}{l}\text { trauma ekstirpasi pulpa } \\
\text { sisa jaringan pulpa } \\
\text { bahan restorasi gigi } \\
\text { bahan perawatan } \\
\text { saluran akar }\end{array}$ & $\begin{array}{l}\text { abu-abu, hitam } \\
\text { coklat, abu-abu, hitam } \\
\text { coklat, abu-abu, hitam } \\
\text { abu-abu, hitam }\end{array}$ \\
\hline Kombinasi & $\begin{array}{l}\text { Fluorosis } \\
\text { Proses ketuaan }\end{array}$ & & $\begin{array}{l}\text { Putih, coklat } \\
\text { Kuning }\end{array}$ \\
\hline
\end{tabular}


merekomendasikan bleaching pada anak di bawah 16 tahun, dengan alasan ruang pulpa pada gigi masih besar pada usia tersebut, sehingga dapat mengiritasi pulpa dan menyebabkan gigi sensitif. ${ }^{2}$

\section{Mekanisme kerja bahan pemutih gigi}

Mekanisme kerja bahan pemutih peroksida dan non-peroksida, yaitu dengan cara masuk melalui perantara enamel ke tubuli dentin dan mengoksidasi pigmen pada dentin, menyebabkan warna gigi menjadi lebih muda. Proses ini dapat dipercepat menggunakan sinar berintensitas rendah atau tinggi, misalnya sinar polimerisasi komposit konvensional, sinar laser, sinar plasma arc dengan intensitas tinggi.

Beberapa pabrik menyarankan penggunaan etsa asam sebelum aplikasi pemutih kimia untuk mempertinggi penetrasi dari bahan pemutih. Akan tetapi, hasil penelitian bahwa etsa tidak memperbaiki hasil pemutihan, bahkan perlu dilakukan pemolesan pada permukaan gigi akibat.

Ada berbagai macam prosedur untuk pemutihan. Pemutihan gigi dapat dikerjakan di klinik oleh dokter gigi secara langsung atau dilakukan di rumah dengan pantauan dokter gigi (tabel 2). Sebelum dilakukan prosedur pemutihan, warna gigi pasien harus didata dengan shade guide terlebih dahulu, sehingga dapat dibedakan dengan hasil warna gigi setelah pemutihan.
Semua produk yang telah disetujui American Dental Association (ADA) untuk dipakai di rumah biasanya menggunakan karbamid peroksida $10 \%$ yang diaplikasikan pada sendok cetak. Produk dengan konsentrasi lebih dari $10 \%$ tidak disetujui sebagai bahan yang aman dan efektif oleh ADA untuk pemakaian di luar klinik gigi.

Pemakaian bahan pemutih di klinik yang dikerjakan oleh dokter gigi dianjurkan untuk penderita yang menginginkan hasil secara singkat, tanpa penggunaan sendok cetak. Penggunaan bahan pemutih tambahan di rumah dianjurkan untuk mempercepat hasil pemutihan.

\section{Indikasi dan kontra indikasi penggunaan bahan pemutih gigi}

Perawatan pemutihan gigi tidak dapat diindikasikan untuk semua orang. Indikasi perawatannya untuk penderita dengan perubahan warna yang disebabkan proses menua, konsumsi makanan dan minuman, fluorosis, serta obat, antara lain tetrasiklin.

Kontra indikasi penggunaan bahan pemutih gigi, adalah alergi terhadap komponen bahan pemutih gigi atau bahan sendok cetak, gigi yang sangat sensitif, gangguan sendi temporomandibula, hamil, restorasi gigi anterior yang berubah warna. Penderita yang terlalu berharap akan hasil pemutihan gigi juga tidak dianjurkan melakukan

Tabel 2. Penggunaan bleaching gigi di rumah maupun di klinik (Sumber: Grossman LI. Ilmu endodontik dalam praktek. Alih bahasa: Yuwono L. Jakarta: EGC; 1995). ${ }^{4}$

\begin{tabular}{|c|c|c|c|}
\hline & Pemutihan gigi di rumah & Pemutihan gigi di klinik & $\begin{array}{c}\text { Pemutihan gigi dengan } \\
\text { kombinasi kekuatan sinar }\end{array}$ \\
\hline $\begin{array}{l}\text { Pilihan } \\
\text { penderita }\end{array}$ & $\begin{array}{l}\text { Penderita dengan perubahan warna } \\
\text { ringan, ingin diputihkan satu atau } \\
\text { dua tingkat dan punya waktu untuk } \\
\text { pemakaian di rumah }\end{array}$ & $\begin{array}{l}\text { Perubahan warna ringan } \\
\text { sampai akut, ingin efek } \\
\text { pemutihan lebih nyata }\end{array}$ & $\begin{array}{l}\text { Penderita dengan perubahan } \\
\text { warna ringan sampai berat, } \\
\text { ingin hasil secara langsung }\end{array}$ \\
\hline $\begin{array}{l}\text { Bahan yang } \\
\text { digunakan }\end{array}$ & $\begin{array}{l}\text { Karbamid peroksida }(10-22 \%) \text { atau } \\
\text { gel pemutih non-peroksida }\end{array}$ & $\begin{array}{l}\text { Karbamid peroksida }(34- \\
44 \%)\end{array}$ & $\begin{array}{l}\text { Hidrogen peroksida }(30- \\
50 \%)\end{array}$ \\
\hline Lokasi & Rumah, 2-4 jam sehari & Klinik gigi & Klinik gigi \\
\hline Teknik & $\begin{array}{l}\text { Buat sendok cetak di klinik. } \\
\text { Sendok cetak dan cairan pemutih } \\
\text { dibawa pulang, kembali ke klinik } \\
\text { periodik untuk kontrol perubahan }\end{array}$ & $\begin{array}{l}\text { Karbamid peroksida pada } \\
\text { sendok cetak, dimasukkan } \\
\text { minimal } 30 \text { menit tiap } \\
\text { terapi. Aplikasi tambahan } \\
\text { di rumah }\end{array}$ & $\begin{array}{l}\text { Cairan diaplikasikan pada } \\
\text { gigi dan diaktivasi dengan } \\
\text { panas atau sinar khusus }\end{array}$ \\
\hline Hasil & $\begin{array}{l}\text { Butuh 3-4 minggu untuk menilai } \\
\text { hasil yang terlihat }\end{array}$ & $\begin{array}{l}\text { Beberapa terlihat setelah } \\
30 \text { menit perawatan }\end{array}$ & $\begin{array}{l}\text { Pada beberapa kasus tampak } \\
\text { langsung berubah warna }\end{array}$ \\
\hline $\begin{array}{l}\text { Rata-rata } \\
\text { jumlah } \\
\text { perawatan }\end{array}$ & $\begin{array}{l}\text { Sekali sehari selama } 2-3 \text { jam untuk } \\
\text { 4-6 minggu }\end{array}$ & $\begin{array}{l}\text { Dapat sebagai perawatan } \\
\text { pertama untuk perawatan } \\
\text { harian di rumah }\end{array}$ & $\begin{array}{l}\text { Satu kunjungan, pemakaian } \\
\text { di rumah tergantung noda } \\
\text { yang akan dihilangkan }\end{array}$ \\
\hline
\end{tabular}


hal ini, karena kemungkinan hasilnya akan mengecewakan. ${ }^{3}$

\section{Metode pemutihan gigi}

Tahap persiapan proses bleaching, meliputi pengamatan visual untuk mengetahui indikasi dan penyebab serta kedalaman penetrasi warna pada gigi dengan melihat kondisi rongga mulut secara menyeluruh, mengetahui riwayat tingkah laku serta kebiasaan yang dapat menjadi salah satu penyebab terjadinya pewarnaan. Pemeriksaan riwayat medis diperlukan untuk mengetahui adanya penyakit sistemik atau pengobatan yang dapat menyebabkan pewarnaan, karena banyak pewarnaan yang terjadi pada masa pertumbuhan dan perkembangan gigi sebelum maupun sesudah lahir. Selain itu perlu dicatat rekam data berupa gambar-gambar pewarnaan sebelum perawatan dilakukan dengan menggunakan kamera video dalam mulut, diperiksa secara menyeluruh kondisi gigi-geligi dan kebersihan mulut dengan menggunakan teknik transluminasi sehingga dapat mendeteksi karies, daerah yang dekalsifikasi atau hipokalsifikasi, adanya sifat tak tembus cahaya, kedalaman dan lapisan dari pewarnaan. Tahap penting lain adalah uji vitalitas gigi karena akan menentukan teknik bleaching yang digunakan. Selain itu, perlu dilakukan profilaksis secara menyeluruh untuk menghilangkan kalkulus dan plak yang merupakan salah satu penyebab pewarnaan ekstrinsik, sehingga pasien bisa saja merasa puas tanpa harus melalui proses bleaching lebih lanjut. $^{7}$

Menurut Walton, ${ }^{5}$ pemutihan gigi dibedakan atas pemutihan internal pada gigi yang non-vital dan pemutihan eksternal pada gigi yang vital.

\section{Pemutihan internal}

Metode yang paling sering digunakan untuk memutihkan gigi pasca perawatan saluran akar adalah teknik walking bleach dan termokatalitik. Teknik walking bleach lebih aman dan lebih cepat pengerjaannya, menggunakan pasta yang merupakan campuran larutan hidrogen peroksida 30-35\% dengan bubuk natrium bikarbonat. Efek maksimal pemutihan dengan teknik ini diperoleh kira-kira 24 jam setelah perawatan, selanjutnya pasien harus kembali setelah 3-7 hari. Teknik termokatalitik dilakukan dengan pelekatan bahan oksidator di dalam kamar pulpa dan penggunaan panas.

\section{Pemutihan eksternal}

Bahan pemutih gigi dimasukkan ke dalam ruang mouthgard yang nantinya akan dipasang menutupi gigi geligi. Pemutihan gigi secara eksternal dilakukan dengan teknik email, mikroabrasi, teknik McInnes, dan teknik mouthguard bleaching.

\section{Efek samping bahan pemutih gigi}

Penggunaan bahan pemutih gigi dapat menimbulkan efek samping berupa rasa terbakar jika menggunakan bahan oksidator dengan konsentrasi tinggi, iritasi pada mukosa gingival karena bahan pemutih yang berlebihan. Efek samping kedua yang sering terjadi adalah gigi sensitif, biasanya terjadi dalam waktu singkat dan dapat ditanggulangi dengan memendekkan waktu proses pemutihan. ${ }^{8}$ Selain itu, juga dapat menyebabkan rasa sakit pada otot pengunyahan dan TMJ bagi penderita yang menggunakan sendok cetak sepanjang malam, karena adanya perubahan posisi kondil. $^{3}$

\section{PEMBAHASAN}

Untuk melakukan perawatan pemutihan gigi pada anak-anak, klinisi harus mengetahui indikasi dan kontraindikasi sebuah perawatan bleaching dan usia anak tersebut karena usia mempunyai hubungan terhadap perkembangan gigi geligi anak. Gigi sulung mulai tumbuh sekitar usia 6 bulan dan tumbuh lengkap sekitar usia 3 tahun. Gigi permanen mulai tumbuh sekitar usia 6 tahun dan lengkap pada usia sekitar 12-14 tahun, kecuali molar ketiga. The American Academy of Pediatric Dentistry (AAPD) tidak menganjurkan melakukan pemutihan semua gigi untuk pasien saat masih dalam tahap geligi pergantian atau berusia di bawah 14 tahun, karena terdapat perbedaan ketebalan email gigi sulung dan gigi permanen. Perbedaan ketebalan email yang menyebabkan warna gigi bervariasi. Pemutihan gigi terhadap seluruh gigi pada saat tahap pergantian gigi, akan mengakibatkan warna gigi permanennya tidak sama. $^{2}$

Bila perubahan warna sampai ke dentin maka harus dilakukan dengan cara bleaching. Bleaching adalah mencerahkan warna gigi menggunakan aplikasi bahan kimia yang mengoksidasi pigmen organik dalam gigi. Cara paling konservatif yang paling ringan dan aman untuk merawat perubahan warna gigi pada anak adalah teknik microabration dengan menghilangkan pit mikro pada daerah enamel gigi yang berubah warna menggunakan bahan abrasif dan asam ringan. Berhasil tidaknya microabration tergantung pada sejumlah faktor, terutama jenis dan banyaknya perubahan warna. Microabration pada email bermanfaat untuk menghilangkan defek demineralisasi dan lesi 
dekalsifikasi. Microabration maupun bleaching dapat digunakan untuk anak berusia 6 atau 7 tahun. $^{2}$

Ada dua metode penggunaan pemutihan gigi, yaitu pemutihan gigi yang dilakukan dokter gigi dan pemutihan gigi sendiri di rumah. Aplikasi nyata pemutihan gigi yang dilakukan oleh dokter gigi, yaitu dengan penggunaan bahan oksidasi konsentrasi tinggi dalam jangka waktu pendek dan cepat serta bisa juga dengan penggunaan light cure. ${ }^{8}$

Cara penggunaan light cure, yaitu dengan cara pengulasan hidrogen peroksida 30-35\% kemudian diaktivasi dengan sinar laser atau plasma arc, dengan waktu kontak sekitar 1 jam. Sementara itu pemutihan gigi juga dapat menggunakan karbamid peroksida yang langsung diaplikasikan pada gigi atau dengan membuat sendok cetak yang sesuai dengan ukuran dan bentuk lengkung gigi. Sendok cetak diisi dengan karbamid peroksida $34-44 \%$ lalu diaplikasikan pada gigi minimal 30 menit setiap perawatan. ${ }^{9}$

Pemutihan gigi di rumah dapat menggunakan mouthguard atau strip yang mengandung bahan oksidasi dengan konsentrasi rendah selama beberapa jam sehari dalam 5-14 hari. Menurut ADA, penggunaan karbamid peroksida $10 \%$ tidak menyebabkan kelainan jaringan lunak secara langsung bila sendok cetak didesain tidak kontak dengan jaringan lunak. Bahan dasar karbamid peroksida $10 \%$ terdiri dari hidrogen peroksida $3 \%$ dan urea $7 \%$. Urea dalam karbamid peroksida berperan sebagai stabilisator yang berguna untuk memperpanjang self life dan memperlambat perlepasan hidrogen peroksida. Produk yang paling aman dan efektif untuk pemakaian di rumah dan telah disetujui $A D A$ pada Maret 2003 adalah Colgate Platinum Daytime Professinal Whitening System 10\%, Nite White Classic Whitening Gel 10\%, Opalescence Whitening Gel 10\%, Patterson Brand Tooth Whitening Gel 10\%, dan Rembrandt Lighten Bleaching Gel 10\%. ${ }^{10}$

Laporan Matis dkk yang dikutip oleh Asti dan Riani, membandingkan penggunaan karbamid peroksida pada konsentrasi $10 \%$ dan $15 \%$, membuktikan hasil pemutihan karbamid peroksida lebih cepat tetapi hasil pemutihan setelah 6 minggu tidak menunjukkan perbedaan. Hal ini berarti karbamid peroksida dengan konsentrasi yang lebih rendah memerlukan waktu lebih lama untuk memutihkan gigi tetapi hasil akhir pemutihan gigi sama setelah 6 minggu. $^{3}$
Sedangkan Zekonis dkk melalui evaluasi klinik, membandingkan perawatan pemutihan gigi di klinik menggunakan hidrogen peroksida 35\% selama 60 menit (2 kali kunjungan) dan perawatan di rumah menggunakan karbamid peroksida $10 \%$ selama 14 hari menunjukkan bahwa $84 \%$ subyek melaporkan perawatan di rumah lebih efisien dan $16 \%$ melaporkan tidak ada perbedaan hasil pemutihan antara di klinik dan di rumah. ${ }^{3}$

\section{SIMPULAN}

Berdasarkan bahasan di atas, disimpulkan bahwa pemilihan cara pemutihan anak tergantung pada jenis stain, perubahan warna dan dalamnya stain. Bila stain pada permukaan email dapat dihilangkan dengan cara microabration, tetapi bila lebih dalam harus dengan cara bleaching. Untuk menggunakan bahan pemutih yang telah disetujui ADA/ISO, dokter gigi harus memiliki pengetahuan mengenai pemutihan gigi di klinik dan di rumah, indikasi dan kontraindikasi, serta efek samping agar dapat memberikan layanan pemutihan gigi yang efektif dan memuaskan.

\section{DAFTAR PUSTAKA}

1. Daryanani RN. Herawati, Wahluyo S. Kadar kalsium dan magnesium enamel gigi sulung setelah aplikasi bahan bleaching. Surabaya; 2000.

2. Irmawati H. Perawatan pemutih pada gigi anak. Indonesia J Dent 2005; 12(2): 25

3. Meizarini A, Riani D. Bahan pemutih gigi dengan sertifikat ADA/ISO. Majalah kedokteran Gigi 2005; 38(2): 25 .

4. Grossman LI. Ilmu endodontik dalam praktek. Alih bahasa: Yuwono L. Jakarta: EGC; 1995.

5. Walton RE. Prinsip dan praktek ilmu endodonsi. Alih bahasa: Yuwono L. Jakarta: EGC; 1997

6. Armilia M. Bleaching (pemutihan) pada gigi yang mengalami perubahan warna. Bandung: FKG Universitas Padjajaran; 2002.

7. Riyanti E. Alternatif pemilihan bahan pada perawatan diskolorisasi gigi tetap anak. Bandung: FKG Universitas Padjajaran; 2006.

8. Anonim. Tooth bleaching. Available at: http//:en.wikipedia.org/wiki/toothbleaching. Diakses pada 7 Mei 2010.

9. Gerlach RW, Barker ML. Professional vital bleaching using a thin and concentrated peroxide gel on whitening strips: an integrated clinical summary (The Procter \& Gamble Company). J Contemp Dent Pract 2004; 5(1):23

10. Donly KJ. Tooth whitening in children. J Compend 2002; 23(1A): 5. 